University of Nebraska - Lincoln

DigitalCommons@University of Nebraska - Lincoln

USDA National Wildlife Research Center - Staff Publications
U.S. Department of Agriculture: Animal and Plant Health Inspection Service

2009

\title{
Threshold Concentrations of an Anthraquinone-Based Repellent for Canada Geese, Red-Winged Blackbirds, and Ring-Necked Pheasants
}

\author{
Scott J. Werner \\ USDA-APHIS-Wildlife Services, scott.j.werner@aphis.usda.gov \\ James C. Carlson \\ USDA/APHIS/WS National Wildlife Research Center, james.c.carlson@aphis.usda.gov \\ Shelagh K. Tupper \\ USDA-APHIS-Wildlife Services \\ Michele M. Santer \\ Arkion Life Sciences \\ George M. Linz \\ USDA/APHIS/WS National Wildlife Research Center, george.m.linz@aphis.usda.gov
}

Follow this and additional works at: https://digitalcommons.unl.edu/icwdm_usdanwrc

Part of the Environmental Sciences Commons

\begin{abstract}
Werner, Scott J.; Carlson, James C.; Tupper, Shelagh K.; Santer, Michele M.; and Linz, George M., "Threshold Concentrations of an Anthraquinone-Based Repellent for Canada Geese, Red-Winged Blackbirds, and Ring-Necked Pheasants" (2009). USDA National Wildlife Research Center - Staff Publications. 983.

https://digitalcommons.unl.edu/icwdm_usdanwrc/983
\end{abstract}

This Article is brought to you for free and open access by the U.S. Department of Agriculture: Animal and Plant Health Inspection Service at DigitalCommons@University of Nebraska - Lincoln. It has been accepted for inclusion in USDA National Wildlife Research Center - Staff Publications by an authorized administrator of DigitalCommons@University of Nebraska - Lincoln. 


\title{
Threshold concentrations of an anthraquinone-based repellent for Canada geese, red-winged blackbirds, and ring-necked pheasants
}

\author{
Scott J. Werner ${ }^{\mathrm{a}, *}$, James C. Carlson ${ }^{\mathrm{a}}$, Shelagh K. Tupper ${ }^{\mathrm{a}}$, Michele M. Santer ${ }^{\mathrm{b}}$, George M. Linz ${ }^{\mathrm{c}}$ \\ ${ }^{a}$ United States Department of Agriculture, Animal and Plant Health, Inspection Service, Wildife Services, National Wildlife Research Center, 4101 LaPorte Avenue, \\ Fort Collins, CO 80521-2154, USA \\ ${ }^{\mathrm{b}}$ Arkion Life Sciences, 551 Mews Drive-Suite J, New Castle, DE 19720, USA \\ ${ }^{\mathrm{c}}$ United States Department of Agriculture, Animal and Plant Health, Inspection Service, Wildlife Services, National Wildlife Research Center, North Dakota Field \\ Station, 2110 Miriam Circle, Bismarck, ND 58501-2502, USA
}

\section{A R T I C L E I N F O}

Article history:

Accepted 27 September 2009

\section{Keywords:}

Agelaius phoeniceus

Aversion

Branta canadensis

Chemical repellent

Conditioned avoidance

Phasianus colchicus

\begin{abstract}
A B S T R A C T
Wildlife repellents provide a non-lethal alternative for managing the monetary impacts of agricultural depredation. For the purpose of developing of an effective avian repellent, we established repellency thresholds of an anthraquinone-based repellent for Canada geese (Branta canadensis), red-winged blackbirds (Agelaius phoeniceus), and ring-necked pheasants (Phasianus colchicus) in captivity. We conducted a concentration-response experiment with Canada geese offered corn seeds treated with six concentrations of Avipel ${ }^{\mathbb{R}}$ repellent (a.i. 50\% 9,10-anthraquinone). Based upon our laboratory efficacy data, we used non-linear regression to predict a threshold concentration of $1450 \mathrm{ppm}$ anthraquinone for geese offered treated corn seeds (i.e., $80 \%$ repellency; $r^{2}=0.85, P=0.009$ ). We also observed a positive concentration-response relationship among red-winged blackbirds offered Avipel ${ }^{\mathbb{R}}$-treated rice $\left(r^{2}=0.70, P=0.039\right)$ and sunflower seeds $\left(r^{2}=0.84, P=0.010\right)$. We predicted a threshold concentration of $1475 \mathrm{ppm}$ anthraquinone for blackbirds offered treated sunflower seeds. Blackbirds also reliably discriminated between untreated food and rice treated with $2325 \mathrm{ppm}$ anthraquinone $\left(F_{1,10}=3414.05, P<0.0001\right)$ or sunflower treated with $1778 \mathrm{ppm}$ anthraquinone $\left(F_{1,10}=175.39, P<0.0001\right)$. We observed a positive concentration-response relationship among ring-necked pheasants offered corn $\left(r^{2}=0.95, P=0.001\right)$ and sunflower seeds $\left(r^{2}=0.99, P<0.001\right)$ treated with Avipel ${ }^{\circledR}$. We predicted a threshold concentration of $10,450 \mathrm{ppm}$ anthraquinone for pheasants offered treated corn seeds. Pheasants also reliably discriminated between untreated food and corn treated with $1900 \mathrm{ppm}$ anthraquinone $\left(F_{1,10}=919.86, P<0.0001\right)$ or hulled sunflower treated with $1140 \mathrm{ppm}$ anthraquinone $\left(F_{1,10}=177.35, P<0.0001\right)$. Avipel ${ }^{\mathbb{R}}$ seed treatments effectively conditioned avoidance of treated seeds among Canada geese, red-winged blackbirds, and ring-necked pheasants. Our laboratory efficacy data provide a reliable basis for planning future field applications of anthraquinone-based bird repellents for protection of agricultural crops, property, and related natural resources. Supplemental field efficacy studies are necessary for registration of anthraquinone-based repellents for managing agricultural depredation caused by wild birds.
\end{abstract}

Published by Elsevier B.V.

\footnotetext{
* Corresponding author. Tel.: +1 970266 6133; fax: +1 9702666138.

E-mail address: Scott.J.Werner@aphis.usda.gov (S.J. Werner).
}

\section{Introduction}

Canada goose (Branta canadensis) populations in North America have increased dramatically during the past 40 years (Ankney, 1996; Sauer et al., 2008). Ankney 
(1996) suggested that waterfowl managers have successfully managed to prevent overharvest of geese for many years; now it is time for them to manage overpopulations of geese. Localized over-abundant Canada goose populations have increased the number of human-wildlife conflicts and magnified their intensity (Werner and Clark, 2006). From 1985 to 1998, geese were ranked as the second greatest hazard to Air Force aircraft in the United States of America (USA) (vultures were the greatest hazard; Zakrajsek and Bissonette, 2005). Among 6741 aircraft strikes reported from 1991 to 1998 , the average cost per strike was greatest (\$36,735 per strike) among those involving geese (Dolbeer et al., 2000). Grazing by Canada geese can negatively impact production of wheat (Flegler et al., 1987), rye (Conover, 1988), and grasses and legumes grown for seed. Canada goose conflicts in the eastern USA include intensive foraging and localized (aquatic and terrestrial) fecal contamination at recreational areas (Conover and Chasko, 1985). The close proximity of geese and humans also increases risk associated with pathogenic bacteria that are prevalent in Canada goose feces (Kullas et al., 2002; see Clark, 2003 for review).

Red-winged blackbirds (Agelaius phoeniceus), common grackles (Quiscalus quiscula), brown-headed cowbirds (Molothrus ater), and yellow-headed blackbirds (Xanthocephalus xanthocephalus) negatively impact growth of newly planted rice in the mid-South of the USA (February-April; Werner et al., 2008a), and production of ripening rice and sunflower in August-October each year (Werner et al., 2005, 2008a,b). Cummings et al. (2005) estimated that blackbirds caused approximately $\$ 13.4$ million of damage to USA rice production in 2001. Similarly, blackbird damage to sunflower was estimated to be $\$ 5.4$ million annually (Peer et al., 2003), or approximately $2 \%$ of the total value of the annual sunflower crop in the USA (Kleingartner, 2003).

The South Dakota Department of Agriculture (Pierre, SD, USA) conducted a poll in February-March 2009 to determine the need for use of an avian repellent to protect newly planted sunflower seed from consumption by ringnecked pheasants (Phasianus colchicus). Approximately $14 \%(N=67)$ of the estimated 478 South Dakota sunflower producers responded to the survey. Among the respondents, $98 \%$ reported sunflower seed or seedling losses from ring-necked pheasants. Forty-two percent of survey respondents reported $<20$ ha damaged by ring-necked pheasants. Sunflower damage attributable to ring-necked pheasants was reportedly $5-10 \%$ yield loss among $19 \%$ of survey respondents, and $11-20 \%$ and $21-50 \%$ yield loss for an additional $19 \%$ and $21 \%$ of respondents, respectively.

Several management alternatives have been used to reduce human-wildlife conflicts in the USA. These alternatives include aversive stimuli (Heinrich and Craven, 1990; Aguilera et al., 1991), non-lethal chemical repellents (Cummings et al., 1995; Dolbeer et al., 1998), trapping, physical exclusion, hunting, and reproductive inhibition (Converse and Kennelly, 1994) for Canada geese. Avian repellents are a socially acceptable, non-lethal approach to managing blackbird depredation of agricultural crops (Cummings et al., 2002a,b; Avery et al., 2005; Linz et al.,
2006; Werner et al., 2007, 2008a,b) and goose-human conflicts (Werner and Clark, 2006).

Anthraquinone was identified as a promising avian repellent in the early 1940s (Heckmanns and Meisenheimer, 1944). Anthraquinone-based repellents have been used effectively protect rice seed from blackbirds under captive and field conditions (Neff and Meanley, 1957; Avery et al., 1997, 1998; Cummings et al., 2002a,b) and turf from Canada goose grazing in captivity (Dolbeer et al., 1998). Feeding reductions among Canada geese offered anthraquinone-treated corn seeds were $70.6 \%, 82.3 \%$, and $96.9 \%$ at $0.05 \%, 0.5 \%$, and $5 \%$ anthraquinone (wt $/ \mathrm{wt}$ ), respectively (Kreithen and Seamans, 1997, unpublished results). Anthraquinone is an emodin (i.e., phenolic) purgative; its action is principally on the large intestine, and it is not effective if transit through the small intestine is delayed (Merck, 1991). Although anthraquinone is a naturally occurring substance, no anthraquinone-based repellents are currently registered for agricultural applications in the USA.

Our purpose was to facilitate the development of an effective repellent for protection of newly planted and ripening crops from avian depredation. Our objective was to determine sufficient (i.e., threshold) concentrations of an anthraquinone-based repellent for wild birds associated with human-wildlife conflicts in the USA. We therefore conducted controlled feeding experiments to evaluate the repellency of varying concentrations of anthraquinone seed treatments with Canada geese, red-winged blackbirds, and ring-necked pheasants in captivity.

\section{Materials and methods}

\subsection{Facilities, subjects and diets}

We conducted feeding experiments in August 2008March 2009 at the United States Department of Agriculture (USDA), National Wildlife Research Center's (NWRC) outdoor animal research facility in Fort Collins, Colorado (USA). We captured 24 Canada geese and 110 red-winged blackbirds, and purchased 55 captive-raised ring-necked pheasants for our concentration-response experiments. Additionally, we captured 22 red-winged blackbirds and purchased 11 captive-raised ring-necked pheasants for our preference experiments. We provided water ad libitum to all birds throughout our experiments. The capture, care, and use of all birds associated with our feeding experiments were approved by the NWRC Animal Care and Use Committee (NWRC Study Protocols QA-1574, QA-1590, QA-1635; S.J. Werner - Study Director).

Geese were maintained in individual cages ( $3 \mathrm{~m} \times 3 \mathrm{~m} \times 2.5 \mathrm{~m}$ ) within wire mesh-sided buildings throughout the study (quarantine, holding, experiment). We maintained all blackbirds in $4.9 \mathrm{~m} \times 2.4 \mathrm{~m} \times 2.4 \mathrm{~m}$ cages (40-50 birds/cage) within a wire mesh-sided building for $\geq 2$ weeks prior to our experiments (i.e., quarantine, holding). Blackbird experiments were conducted in individual cages $(0.9 \mathrm{~m} \times 1.8 \mathrm{~m} \times 0.9 \mathrm{~m})$ within a wire mesh-sided building. Pheasants were maintained in individual cages $(0.9 \mathrm{~m} \times 1.8 \mathrm{~m} \times 0.9 \mathrm{~m})$ within a wire 
mesh-sided building throughout the study (quarantine, holding, experiments).

We provided free access to grit and a maintenance diet to all birds during quarantine and holding. The maintenance diet for geese and pheasants included three parts whole corn:one game bird feed (Purina Mills, St. Louis, MO, USA). The maintenance diet for blackbirds included two parts millet:one cracked corn:one milo:one safflower. We used Avipel ${ }^{\circledR}$ repellent (a.i. 50\% 9,10-anthraquinone; Arkion Life Sciences, New Castle, DE, USA) for our goose and blackbird feeding experiments in 2008 and our pheasant experiments in 2009. We formulated seed treatments for our experiments by applying aqueous solutions $(60 \mathrm{~mL} / \mathrm{kg})$ to rice seed (Missouri Foundation Seed, Portageville, MO, USA), and whole corn, whole oilseed sunflower, and hulled sunflower (Ranch-Way Feed Mills, Fort Collins, CO, USA) using a rotating mixer and household spray equipment.

\subsection{Concentration-response experiments}

We conducted five experiments to establish a concentration-response relationship of anthraquinone-treated seeds for Canada geese, red-winged blackbirds, and ringnecked pheasants in captivity. We used a choice test to refine the concentration-response relationship previously established for Canada geese offered corn seeds treated with $0.0005 \%, 0.005 \%, 0.05 \%, 0.5 \%$, and $5 \%$ anthraquinone (Kreithen and Seamans, 1997, unpublished results). We used no-choice tests to establish concentration-response relationships for red-winged blackbirds and ring-necked pheasants (Werner et al., 2007, 2008a,b). Daily seed consumption was measured throughout the concentration-response experiments. Unconsumed seeds (remaining in food bowls) and spillage were collected (at 08:00 to 09:30 h, daily) and weighed $( \pm 0.1 \mathrm{~g})$. Weight change (e.g., desiccation) of seeds was measured daily by weighing seeds offered within a vacant cage throughout our experiments.

We offered maintenance food ad libitum to 24 Canada geese in two food bowls for 5 days of acclimation in individual cages. We randomly assigned all geese to one of three groups ( $n=8$ geese/group) and offered them two food bowls ( $100 \mathrm{~g}$ whole corn, each) from 07:00 to 08:00 h, daily for 4 days. On study days 1 and 2, we offered all geese in each group one bowl of untreated corn and one bowl of corn treated with $0.02 \%$ anthraquinone (targeted concentration, wt/wt; group 1), 0.035\% anthraquinone (group 2), or $0.05 \%$ anthraquinone (group 3 ). On study days 3 and 4 , we offered each goose one bowl of untreated corn and one bowl of corn treated with $0.1 \%$ anthraquinone (group 1 ), $0.25 \%$ anthraquinone (group 2 ), or $0.4 \%$ anthraquinone (group 3). The north-south placement of food bowls was randomized on the first day and alternated on subsequent days of the experiment.

We offered 55 red-winged blackbirds untreated sunflower seed ad libitum in one food bowl for 5 days of acclimation in individual cages. We subsequently offered each blackbird $30 \mathrm{~g}$ of untreated sunflower seeds in one bowl during each of study days $1-3$. We ranked blackbirds based upon average pretreatment consumption and assigned them to one of six treatment groups $(n=9-10$ blackbirds/group) such that each group was similarly populated with birds that exhibited high-low daily consumption. We randomly assigned treatments among groups $(0.02 \%, 0.035 \%, 0.05 \%, 0.1 \%, 0.25 \%$, and $0.5 \%$ anthraquinone; targeted concentrations, wt/wt). We offered $30 \mathrm{~g}$ of treated sunflower seeds in one bowl to all birds on study day 4 , and determined the mass ( $\pm 0.1 \mathrm{~g})$ of uneaten seeds and seed spillage at 08:00 to 09:30 h on study day 5 . We repeated all acclimation, pretreatment, and treatment procedures with the remaining 55, experimentally naïve blackbirds offered anthraquinone-treated rice seeds.

We replicated the blackbird concentration-response experiments with 55 ring-necked pheasants offered anthraquinone-treated hulled sunflower and whole corn seeds ( $n=9-10$ pheasants/group). Our pheasant experiments were conducted for 2 weeks. We offered all pheasants one bowl of hulled sunflower treated with $0.02 \%, 0.035 \%, 0.05 \%, 0.1 \%, 0.25 \%$, or $0.5 \%$ anthraquinone (i.e., targeted concentrations) on study day 4 (week 1 ), and one bowl of corn seeds treated with $0.1 \%, 0.25 \%, 0.5 \%, 1 \%$, $1.5 \%$, or $2.0 \%$ anthraquinone on study day 9 (week 2 ) of our pheasant concentration-response experiments.

\subsubsection{Statistical analysis}

We hypothesized that repellency would be directly related to repellent concentration during our concentration-response experiments. We previously established $\geq 80 \%$ repellency as efficacious during our laboratory feeding experiments (Werner et al., 2007, 2008a,b). Thus, we predicted that consumption of efficacious treatments (i.e., threshold repellency) would be $<20 \%$ of untreatedseed consumption for the goose concentration-response experiment, and $<20 \%$ of pretreatment consumption for the blackbird and pheasant concentration-response experiments. The dependent measure for the goose concentration-response experiment was calculated as average test consumption of treated seeds relative to untreated seeds (i.e., percent repellency). The dependent measure for the blackbird and pheasant concentrationresponse experiments was calculated as test consumption relative to average pretreatment consumption (percent repellency). We used non-linear regression procedures (SAS v9.1) to analyze repellency as a function of anthraquinone concentration (ppm). We used descriptive statistics $(\bar{x} \pm$ S.E.M.) to summarize consumption (mg anthraquinone $/ \mathrm{kg}$ body mass [BM]) of treated seeds during concentration-response experiments.

\subsection{Preference experiments}

We conducted four preference (i.e., choice) experiments to evaluate red-winged blackbird consumption of treated versus untreated sunflower and rice seeds, and ring-necked pheasant consumption of treated versus untreated hulled sunflower and corn seeds. Daily seed consumption was measured throughout the preference experiments (study days 1-4). Unconsumed seeds (remaining in food bowls) and spillage were collected (at 08:00 to 09:30 h, daily) and weighed ( $\pm 0.1 \mathrm{~g}$ ). Consumption was measured independently for the north and south food bowls. Weight change (e.g., desiccation) of seeds 
was again measured daily by weighing seeds offered within a vacant cage throughout our preference experiments.

We randomly assigned 11 red-winged blackbirds to our sunflower preference experiment. We offered all blackbirds untreated sunflower seed ad libitum in two food bowls for 5 days of acclimation in individual cages. We subsequently offered each blackbird one bowl of untreated sunflower and one bowl of sunflower treated with $0.25 \%$ anthraquinone (targeted concentration, wt/wt) at 08:00 to 09:30 h, daily. The north-south placement of food bowls was randomized on the first day and alternated on subsequent days of the experiment. We repeated all acclimation and treatment procedures with the remaining 11, experimentally naïve blackbirds offered untreated rice seeds and rice seeds treated with $0.25 \%$ anthraquinone.

We replicated the blackbird preference experiments with 11 ring-necked pheasants offered anthraquinonetreated hulled sunflower or whole corn seeds. Our pheasant experiments were conducted for 2 weeks. During the first week, we offered all pheasants one bowl of untreated sunflower and one bowl of sunflower treated with $0.25 \%$ anthraquinone at $08: 00$ to $09: 30 \mathrm{~h}$, daily. During the second week, we offered all pheasants one bowl of untreated corn seeds and one bowl of corn seeds treated with $0.25 \%$ anthraquinone at $08: 00$ to $09: 30 \mathrm{~h}$, daily.

\subsubsection{Statistical analysis}

The dependent measure for our preference experiments was average (i.e., daily) test consumption of treated and untreated seeds. Consumption data for each preference experiment were subjected to a repeated measures analysis of variance (ANOVA). The random effect of our models was bird subjects, the between-subjects effect was treatment (treated versus untreated seed), and the withinsubject effect was test day. We analyzed the treatment effect and the treatment by day interaction using a mixed model (SAS v9.1). We used Tukey's tests to separate means of ANOVA interactions $(\alpha=0.05)$. We used descriptive statistics $(\bar{x} \pm$ S.E.M. $)$ to summarize consumption of treated and untreated seeds during preference experiments.

\subsection{Anthraquinone residue analyses}

We used reversed-phase, high performance liquid chromatography (HPLC; Table 1) with ultraviolet detection to quantify anthraquinone residues (i.e., actual concentrations) among our corn, rice, and sunflower seed treatments ( $\pm 1 \mathrm{ppm}$ anthraquinone). We collected a $200 \mathrm{~g}$ sample of each seed treatment associated with our concentrationresponse and preference experiments. All samples were labeled and shipped to Arkion Life Sciences for subsequent residue analyses. Samples were received by Arkion Life Sciences within $24 \mathrm{~h}$ of formulation, logged in, and immediately transferred to a $4{ }^{\circ} \mathrm{C}$ refrigerator where they were stored for the duration of the analysis period.

We extracted and analyzed triplicate subsamples from each seed treatment. Samples of each seed type were fortified with 350 and $1000 \mathrm{ppm}$ anthraquinone, and extracted to determine the recovery rate for the assay. We weighed $1.0( \pm 0.2) \mathrm{g}$ of whole seed into $24 \mathrm{~mL}$ glass vials
Table 1

Typical high performance liquid chromatography conditions used to determine anthraquinone residue concentrations among corn, rice, and sunflower seed treatments used for laboratory efficacy testing of anthraquinone-based avian repellents at the National Wildlife Research Center in Fort Collins, Colorado (USA), August 2008-March 2009.

\begin{tabular}{ll}
\hline Parameter & Operating conditions \\
\hline Mobile phase & 80 methanol:20 water \\
Flow rate & $1 \mathrm{~mL} / \mathrm{min}$ \\
Injection volume & $10 \mu \mathrm{L}$ \\
Column & Zorbax SB (C8), $5 \mu \mathrm{m}, 4.6 \mathrm{~cm} \times 25 \mathrm{~cm}$ \\
Detector & Ultraviolet @ $254 \mathrm{~nm}$ \\
\hline
\end{tabular}

fitted with Teflon lined caps. We pipetted $10 \mathrm{~mL}$ of methylene chloride into each vial using a glass volumetric pipette. We then recorded the weight of the extract. Extraction was accomplished by vortexing each vial for $20 \mathrm{~s}$, and then twice sonicating for $20 \mathrm{~min}$ (vortexing each time). We filtered a $0.7 \mathrm{~g}$ aliquot of each extract through a $0.2 \mu \mathrm{m}$ Nylon filter into a weighed evaporation vial. After capping, the evaporation vial was reweighed, and extract was evaporated to dryness under a gentle Helium stream. The extract was dissolved using $2 \mathrm{~mL}$ of methanol and sonicated for $20 \mathrm{~min}$. Sample solutions were transferred into autosampler vials and analyzed by HPLC.

We used a five-point external calibration curve to calibrate our HPLC instrument. Samples were run in duplicate each day, and we checked single calibration points upon each 10 injections. The average response was plotted against anthraquinone concentrations. We used linear regression to calculate sample concentrations. The method detection limit (MDL) of our analyses was $0.010 \mathrm{ng} / \mathrm{mL}$.

\section{Results}

\subsection{Concentration-response experiments}

We observed a positive concentration-response relationship during each of our concentration-response experiments. Canada geese exhibited $>80 \%$ repellency for corn treated with $1764 \mathrm{ppm}$ anthraquinone (Fig. 1), or $13.8 \pm 3.4 \mathrm{mg}$ anthraquinone/ $\mathrm{kg}$ BM. Goose repellency $(y)$ was a function of anthraquinone concentration $(x)$ : $y=24.65 \ln (x)-99.26 \quad\left(r^{2}=0.85, P=0.009\right)$. We therefore predicted a threshold concentration of 1450 ppm anthraquinone (i.e., $80 \%$ repellency) for geese offered treated corn seeds.

Red-winged blackbirds exhibited $>80 \%$ repellency for sunflower treated with 1994 ppm anthraquinone (Fig. 2), or $17.1 \pm 12.6 \mathrm{mg}$ anthraquinone/kg BM. Blackbird repellency among sunflower seed treatments was described as $y=33.72 \ln (x)-166.00\left(r^{2}=0.84, P=0.010\right)$. We therefore predicted a threshold concentration of 1475 ppm anthraquinone for blackbirds offered treated sunflower seeds. Although blackbird repellency was directly related to concentrations of our rice seed treatments $\left(r^{2}=0.70\right.$, $P=0.039$ ), maximum repellency was only $79 \%$ for the highest concentration tested (4921 ppm anthraquinone).

Although ring-necked pheasant repellency was directly related to concentrations of our hulled sunflower treat- 


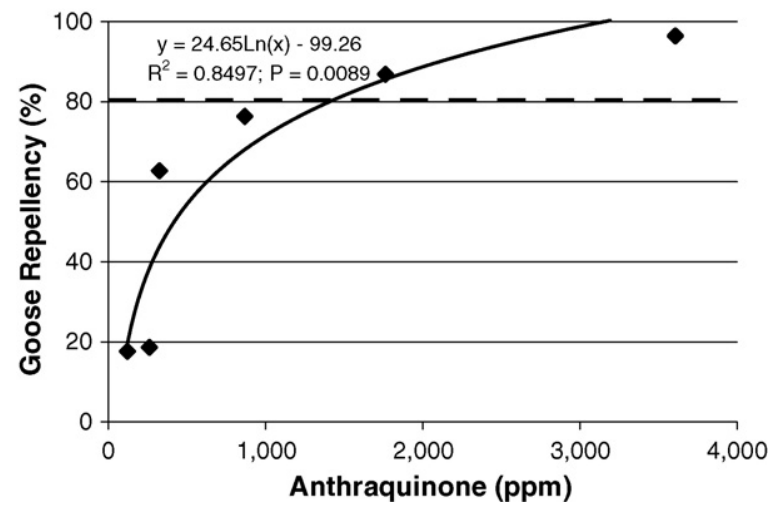

Fig. 1. Mean feeding repellency associated with six concentrations of Avipel ${ }^{\mathbb{R}}$ seed treatments (a.i. 50\% 9,10-anthraquinone; Arkion ${ }^{\mathbb{R}}$ Life Sciences, New Castle, DE, USA) offered to Canada geese (Branta canadensis) at the National Wildlife Research Center in Fort Collins, Colorado (USA), August 2008. Repellency represents consumption of treated versus untreated corn offered concurrently during the 2-day experiment ( $n=8$ geese/concentration).

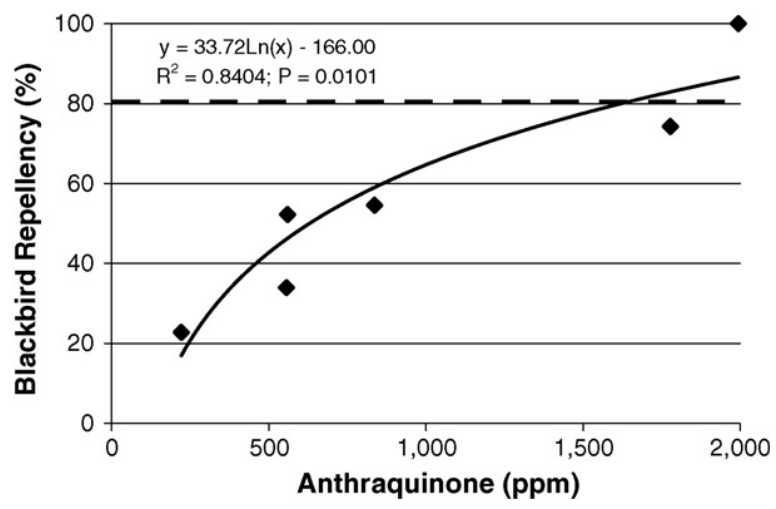

Fig. 2. Mean feeding repellency associated with six concentrations of Avipel $^{\mathbb{B}}$ seed treatments (a.i. 50\% 9,10-anthraquinone; Arkion ${ }^{\mathbb{R}}$ Life Sciences, New Castle, DE, USA) offered to red-winged blackbirds (Agelaius phoeniceus) at the National Wildlife Research Center in Fort Collins, Colorado (USA), November 2008. Repellency represents test consumption relative to average, pretreatment sunflower consumption ( $n=9-10$ blackbirds/concentration).

ments $\left(r^{2}=0.99, P<0.001\right)$, maximum repellency was only $66 \%$ for the highest concentration tested (1310 ppm anthraquinone). Pheasants exhibited $>80 \%$ repellency for corn treated with $9000 \mathrm{ppm}$ anthraquinone (Fig. 3), or $52.4 \pm 20.8 \mathrm{mg}$ anthraquinone/kg BM. Pheasant repellency among corn seed treatments was described as $y=$ $16.37 \ln (x)-71.47\left(r^{2}=0.95, P=0.001\right)$. We therefore predicted a threshold concentration of $10,450 \mathrm{ppm}$ anthraquinone for pheasants offered treated corn seeds.

\subsection{Preference experiments}

Blackbirds reliably discriminated between untreated sunflower seeds and those treated with $1778 \mathrm{ppm}$ anthraquinone $\left(F_{1,10}=175.39, P<0.0001\right)$. Blackbirds consumed an average of $0 \pm 0.2 \mathrm{~g}$ of treated sunflower and $6.5 \pm 0.4 \mathrm{~g}$ of untreated sunflower during the 4-day experiment (Fig. 4a). We observed no treatment by day interaction

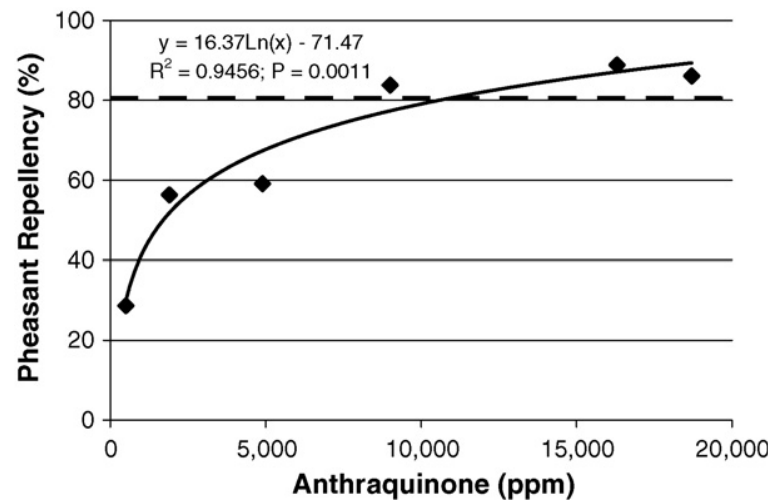

Fig. 3. Mean feeding repellency associated with six concentrations of Avipel $^{\mathbb{B}}$ seed treatments (a.i. 50\% 9,10-anthraquinone; Arkion ${ }^{\mathbb{B}}$ Life Sciences, New Castle, DE, USA) offered to ring-necked pheasants (Phasianus colchicus) at the National Wildlife Research Center in Fort Collins, Colorado (USA), March 2009. Repellency represents test consumption relative to average, pretreatment corn consumption ( $n=7-9$ pheasants/concentration).

during the sunflower preference experiment $\left(F_{6,60}=1.00\right.$, $P=0.435$ ).

Blackbirds also preferred untreated rice relative to rice treated with $2325 \mathrm{ppm}$ anthraquinone during the preference experiment $\left(F_{1,10}=3414.05, P<0.0001\right)$. Blackbirds consumed an average of $0 \pm 0.1 \mathrm{~g}$ of treated rice and $10.8 \pm 0.2 \mathrm{~g}$ of untreated rice during the 4-day experiment (Fig. 4b). We also observed a treatment by day interaction during the rice preference experiment $\left(F_{6,56}=10.64\right.$, $P<0.0001)$; blackbirds consumed less untreated rice on test day 1 relative to days $2-4$ (Tukey $P<0.05$ ).

Pheasants reliably discriminated between untreated sunflower and that treated with $1140 \mathrm{ppm}$ anthraquinone $\left(F_{1,10}=177.35, P<0.0001\right)$. Pheasants consumed an average of $1.2 \pm 0.3 \mathrm{~g}$ of treated sunflower and $20.7 \pm 1.6 \mathrm{~g}$ of untreated sunflower during the 4-day experiment (Fig. 4c). We observed no treatment by day interaction during the sunflower preference experiment $\left(F_{6,60}=0.72, P=0.634\right)$.

Pheasants also preferred untreated corn relative to corn treated with $1900 \mathrm{ppm}$ anthraquinone $\left(F_{1,10}=919.86\right.$, $P<0.0001)$. Pheasants consumed an average of $0.1 \pm$ $0.2 \mathrm{~g}$ of treated corn and $40.6 \pm 1.7 \mathrm{~g}$ of untreated corn during the 4-day experiment (Fig. 4d). We also observed a treatment by day interaction during the corn preference experiment $\left(F_{6,60}=4.33, P=0.001\right)$; pheasants consumed more untreated corn on test day 4 relative to days 1 and 2 (Tukey $P<0.05$ ).

\section{Discussion}

We observed both inter- and intra-specific variation among wild birds offered varying concentrations of anthraquinone-treated seeds. Based upon our non-linear regression model, we predicted threshold concentrations of anthraquinone-based repellents for Canada geese, redwinged blackbirds, and ring-necked pheasants (Table 2). We refined the concentration-response relationship previously established for Canada geese (i.e., 70.6\% and $82.3 \%$ feeding reductions at $0.05 \%, 0.5 \%$ anthraquinone, respectively; Kreithen and Seamans, 1997, unpublished results). 
(a)

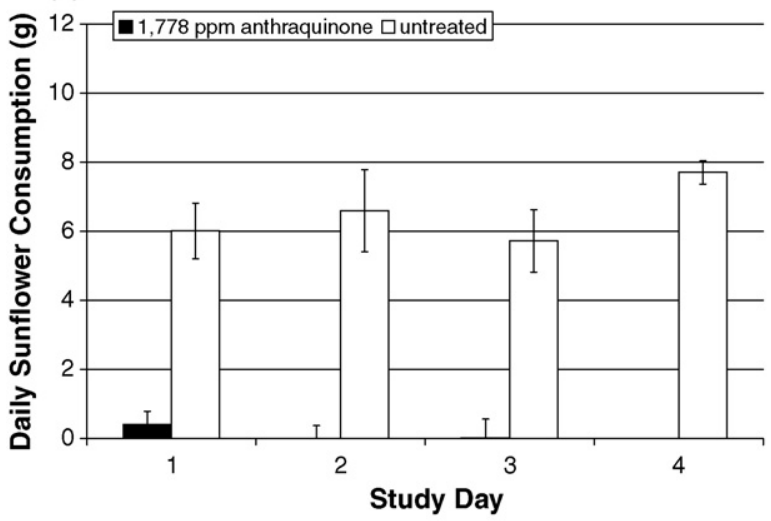

(c)

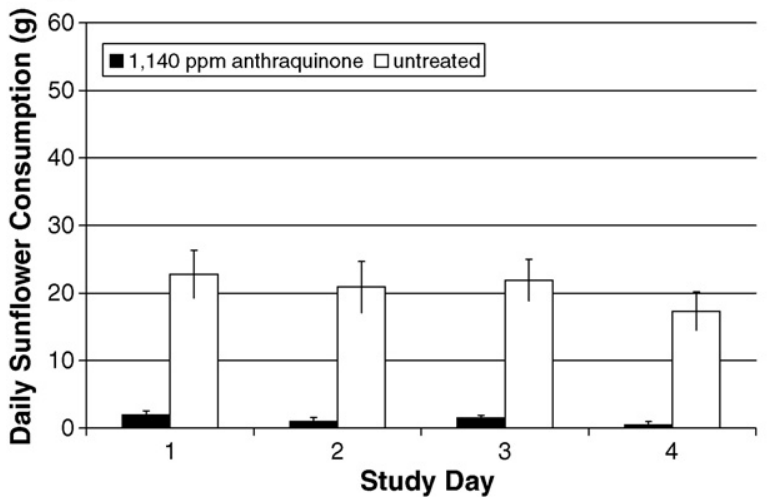

(b)

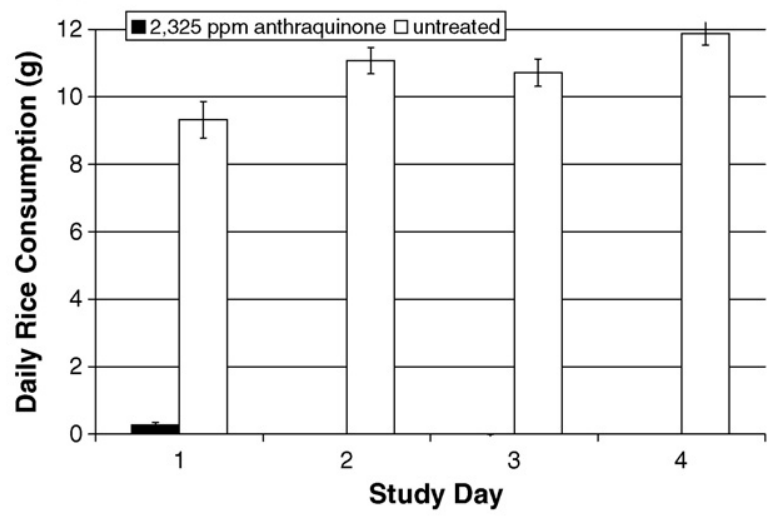

(d)

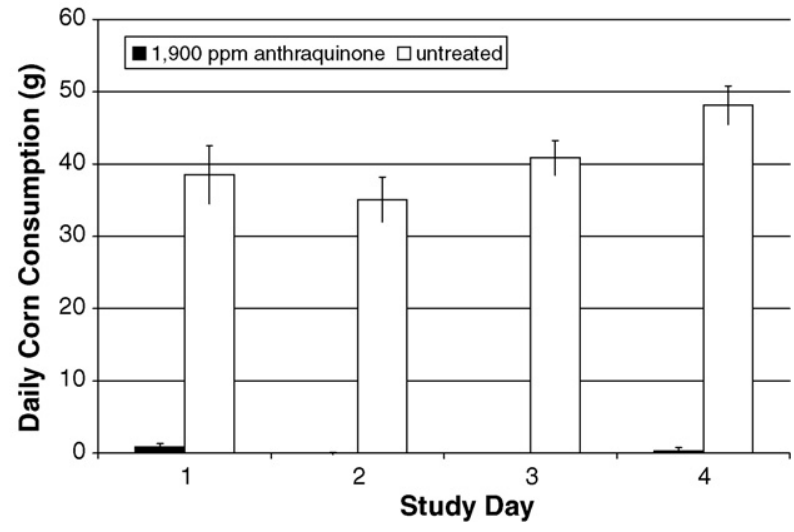

Fig. 4. Mean consumption ( \pm S.E.M.) of sunflower seeds (a) and rice seeds (b) offered to red-winged blackbirds ( $A$. phoeniceus, $n=11$; November-December 2008), and hulled sunflower (c) and corn seeds (d) offered to ring-necked pheasants ( . colchicus, $n=11$; March 2009) at the National Wildlife Research Center in Fort Collins, Colorado (USA). Blackbirds were offered untreated seeds and seeds treated with Avipel ${ }^{\mathbb{R}}$ (a.i. 50\% 9,10-anthraquinone; Arkion ${ }^{\mathbb{R}}$ Life Sciences, New Castle, DE, USA). Pheasants were offered untreated seeds and seeds treated with Avipel ${ }^{\circledR}$ (a.i. 50\% 9,10-anthraquinone; Arkion ${ }^{\circledR}$ Life Sciences).

Interestingly, the body mass of wild birds associated with our feeding experiments was not directly related to anthraquinone concentrations sufficient for threshold repellency (Table 2 ). Thus, additional studies are needed to investigate inter-specific responses and mechanisms of anthraquinone-based repellents.

Whereas anthraquinone is an emodin purgative, consumption of anthraquinone-treated seeds may affect

\section{Table 2}

Threshold concentrations of anthraquinone-based repellents for wild birds associated with human-wildlife conflicts in the United States. Threshold repellency (targeted $80 \%$ feeding reduction) was estimated from regression models based upon concentration-response experiments conducted at the National Wildlife Research Center in Fort Collins, Colorado (USA), August 2008-March 2009.

\begin{tabular}{lcll}
\hline Subject & $\begin{array}{l}\text { Body } \\
\text { mass } \\
(\mathrm{kg})\end{array}$ & Seed & $\begin{array}{l}\text { Threshold } \\
\text { concentration } \\
\text { (anthraquinone, } \\
\text { ppm) }\end{array}$ \\
\hline Canada goose & $4.3-4.8$ & Corn & 1,450 \\
Red-winged blackbird & $0.05-0.08$ & $\begin{array}{l}\text { Sunflower } \\
\text { Rice }\end{array}$ & 1,475 \\
Ring-necked pheasant & $1.2-1.4$ & $\begin{array}{l}\text { Hulled } \\
\text { sunflower } \\
\text { Corn }\end{array}$ & $>2,000$ \\
& & Con & 10,450 \\
\hline
\end{tabular}

malabsorption and dehydration. Interestingly, anthraquinone also absorbs near-ultraviolet light (Du et al., 1998) that is visible to most birds (i.e., 300-400 nm; Hart and Hunt, 2007). Based upon these characteristics (i.e., inextricable sensory cue + postingestive consequence; Domjan, 1985), anthraquinone is a quintessential avoidance-conditioning agent for wild birds. We previously identified the cognitive basis for color cue/repellent consequence conditioning in red-winged blackbirds (Werner et al., 2008c). We therefore hypothesize that the intra-specific variation observed during our blackbird feeding experiments may be attributable to background coloration of anthraquinone-treated seeds (e.g., sunflower versus rice; Table 2).

The ultimate effectiveness of chemical repellents is dependent upon their efficacy under field conditions, cost relative to expected damages of unmanaged crops, environmental impacts (e.g., oral rat $\mathrm{LD}_{50}>5000 \mathrm{mg} / \mathrm{kg}$; Arkion Life Sciences), and food and feed safety. Optimized repellent formulations and application strategies are needed for protection of newly planted and ripening crops in context of these economic, environmental, and safety thresholds. For example, ultraviolet cues may enhance repellency of cost-effective applications of anthraquinonebased repellents throughout the period of needed repellency (Werner, 2009; Ultraviolet Strategy for Avian 
Repellency, USA patent application). We recommend supplemental field research to evaluate the spatial extent of inferences from our captive feeding experiments. We further recommend additional field trials ( $>500$ ha) of anthraquinone-based repellents to reconcile field efficacy and crop residues with our predicted threshold concentrations.

\section{Conclusion}

Avipel ${ }^{\circledR}$ seed treatments (a.i. 9,10-anthraquinone) effectively conditioned avoidance of treated seeds among Canada geese, red-winged blackbirds, and ring-necked pheasants in captivity. Our laboratory efficacy data and our predicted threshold concentrations provide a reliable basis for planning future field applications of anthraquinone-based bird repellents for protection of agricultural crops, property, and related natural resources. Field efficacy studies designed to maintain threshold repellent concentrations throughout the period of needed repellency are necessary for registration of anthraquinone-based repellents for managing agricultural depredation caused by wild birds.

\section{Acknowledgements}

This research was supported by the Louisiana Rice Research Board, the Louisiana State University Rice Research Station, the Rice Foundation, the U.S.A. Rice Federation, and the National Sunflower Association. Our feeding experiments were conducted with Avipel ${ }^{\circledR}$ repellents (Arkion ${ }^{\circledR}$ Life Sciences, New Castle, DE, USA). Corporate collaborations do not imply endorsement by the United States Department of Agriculture. We appreciate the National Wildlife Research Center animal care staff that provided daily care throughout our feeding experiments. We also thank J.D. Eisemann, R.G. McLean, S. Pettit, and M.E. Tobin for constructive feedback from their review of our manuscript.

\section{References}

Aguilera, E., Knight, R.L., Cummings, J.L., 1991. An evaluation of two hazing methods for urban Canada geese. Wildl. Soc. Bull. 19, 32-35.

Ankney, C.D., 1996. An embarrassment of riches: too many geese. J. Wildl. Manage. 60, 217-223.

Avery, M.L., Humphrey, J.S., Decker, D.G., 1997. Feeding deterrence of anthraquinone, anthracene, and anthrone to rice-eating birds. J. Wildl. Manage. 61, 1359-1365.

Avery, M.L., Humphrey, J.S., Primus, T.M., Decker, D.G., McGrane, A.P., 1998. Anthraquinone protects rice seed from birds. Crop Prot. 17, 225-230.

Avery, M.L., Werner, S.J., Cummings, J.L., Humphrey, J.S., Milleson, M.P. Carlson, J.C., Primus, T.M., Goodall, M.J., 2005. Caffeine for reducing bird damage to newly seeded rice. Crop Prot. 24, 651-657.

Clark, L., 2003. A review of pathogens of agricultural and human health interest found in Canada geese. Wildl. Damage Manage. Conf. 10, 326-334.

Conover, M.R., 1988. Effect of grazing by Canada geese on the winter growth of rye. J. Wildl. Manage. 52, 76-80.

Conover, M.R., Chasko, G.G., 1985. Nuisance Canada goose problems in the eastern United States. Wildl. Soc. Bull. 13, 228-233.
Converse, K.A., Kennelly, J.J., 1994. Evaluation of Canada goose sterilization for population control. Wildl. Soc. Bull. 22, 265-269.

Cummings, J.L., Avery, M.L., Mathre, O., Wilson, E.A., York, D.L., Engeman, R.M., Pochop, P.A., Davis Jr., J.E., 2002a. Field evaluation of Flight Control $^{\mathrm{TM}}$ to reduce blackbird damage to newly planted rice. Wildl. Soc. Bull. 30, 816-820.

Cummings, J.L., Pochop, P.A., Davis Jr., J.E., Krupa, H.W., 1995. Evaluation of Rejex-It AG-36 as a Canada goose grazing repellent. J. Wildl. Manage. 59, 47-50.

Cummings, J.L., Pochop, P.A., Engeman, R.M., Davis Jr., J.E., Primus, T.M., 2002b. Evaluation of Flight Control ${ }^{\mathbb{R}}$ to reduce blackbird damage to newly planted rice in Louisiana. Int. Biodeter. Biodeg. 49, 169-173.

Cummings, J.L., Shwiff, S.A., Tupper, S.K., 2005. Economic impacts of blackbird damage to the rice industry. Wildl. Dam. Manage. Conf. 11, 317-322.

Dolbeer, R.A., Seamans, T.W., Blackwell, B.F., Belant, J.L., 1998. Anthraquinone formulation (Flight Control ${ }^{\mathrm{TM}}$ ) shows promise as avian feeding repellent. J. Wildl. Manage. 62, 1558-1564.

Dolbeer, R.A., Wright, S.E., Cleary, E.C., 2000. Ranking the hazard level of wildlife species to aviation. Wildl. Soc. Bull. 28, 372-378.

Domjan, M., 1985. Cue-consequence specificity and long-delay learning revisited. Ann. NY Acad. Sci. 443, 54-66.

Du, H., Fuh, R.A., Li, J., Corkan, A., Lindsey, J.S., 1998. PhotochemCAD: a computer aided design and research tool in photochemistry. Photochem. Photobiol. 68, 141-142.

Flegler Jr., E.J., Prince, H.H., Johnson, W.C., 1987. Effects of grazing by Canada geese on winter wheat yield. Wildl. Soc. Bull. 15, 402-405.

Hart, N.S., Hunt, D.M., 2007. Avian visual pigments: characteristics, spectral tuning, and evolution. Am. Nat. 169 (Suppl.), S7-S26.

Heckmanns, F., Meisenheimer, M., 1944. Protection of seeds against birds. Patent 2,339,335. U.S. Patent Office, Washington, DC.

Heinrich, J.W., Craven, S.R., 1990. Evaluation of three damage abatement techniques for Canada geese. Wildl. Soc. Bull. 18, 405-410.

Kleingartner, L., 2003. Sunflower losses to blackbirds: an economic burden. In: Linz, G.M. (Ed.), Management of North American Blackbirds. United States Department of Agriculture, Washington, DC, pp. 13-14.

Kullas, H., Coles, M., Rhyan, J., Clark, L., 2002. Prevalence of Escherichia coli serogroups and human virulence factors in faeces of urban Canada geese (Branta canadensis). Int. J. Environ. Health Res. 23, 153-162.

Linz, G.M., Homan, H.J., Slowik, A.A., Penry, L.B., 2006. Evaluation of registered pesticides as repellents for reducing blackbird (Icteridae) damage to sunflower. Crop Prot. 25, 842-847.

Merck, 1991. In: Fraser, C.M., Bergeron, J.A. (Eds.), Merck Veterinary Manual. 7th ed. Merck \& Co. Inc., USA, p. 1383.

Neff, J.A., Meanley, B., 1957. Research on Bird Repellents: Bird Repellent Studies in the Eastern Arkansas Rice Fields. Wildl. Res. Lab., Denver, CO, 21 pp.

Peer, B.D., Homan, H.J., Linz, G.M., Bleier, W.J., 2003. Impact of blackbird damage to sunflower: bioenergetic and economic models. Ecol. Appl. $13,248-256$

Sauer, J.R., Hines, J.E., Fallon, J., 2008. The North American Breeding Bird Survey. Results and Analysis 1966-2007. United States Geological Survey, Patuxent Wildlife Research Center, Laurel, MD, USA.

Werner, S.J., Clark, L., 2006. Effectiveness of a motion-activated laser hazing system for repelling captive Canada geese. Wildl. Soc. Bull. 34, 2-7.

Werner, S.J., Cummings, J.L., Pipas, P.A., Tupper, S.K., Byrd, R.W., 2008a. Registered pesticides and citrus terpenes as blackbird repellents for rice. J. Wildl. Manage. 72, 1863-1868.

Werner, S.J., Cummings, J.L., Tupper, S.K., Goldade, D.A., Beighley, D., 2008b. Blackbird repellency of selected registered pesticides. J. Wildl. Manage. 72, 1007-1011.

Werner, S.J., Cummings, J.L., Tupper, S.K., Hurley, J.C., Stahl, R.S., Primus, T.M., 2007. Caffeine formulation for avian repellency. J. Wildl. Manage. $71,1676-1681$.

Werner, S.J., Homan, H.J., Avery, M.L., Linz, G.M., Tillman, E.A., Slowik, A.A., Byrd, R.W., Primus, T.M., Goodall, M.J., 2005. Evaluation of Bird Shield ${ }^{\mathrm{TM}}$ as a blackbird repellent in ripening rice and sunflower fields. Wildl. Soc. Bull. 33, 251-257.

Werner, S.J., Kimball, B.A., Provenza, F.D., 2008c. Food color, flavor, and conditioned avoidance among red-winged blackbirds. Physiol. Behav. 93, 110-117.

Zakrajsek, E.J., Bissonette, J.A., 2005. Ranking the risk of wildlife species hazards to military aircraft. Wildl. Soc. Bull. 33, 258-264. 